\title{
Soil-Borne Microbial Functional Structure across Different Land Uses
}

\author{
Eiko E. Kuramae, ${ }^{1}$ Jizhong Z. Zhou, ${ }^{2}$ George A. Kowalchuk, ${ }^{3}$ and Johannes A. van Veen ${ }^{1,4}$ \\ ${ }^{1}$ Department of Microbial Ecology, Netherlands Institute of Ecology (NIOO-KNAW), 6708 PB Wageningen, The Netherlands \\ ${ }^{2}$ Institute for Environmental Genomics, University of Oklahoma, Norman, OK 73019, USA \\ ${ }^{3}$ Department of Biology, Utrecht University, 3512 JE Utrecht, The Netherlands \\ ${ }^{4}$ Institute of Biology, Leiden University, 2311 EZ Leiden, The Netherlands
}

Correspondence should be addressed to Eiko E. Kuramae; e.kuramae@nioo.knaw.nl

Received 29 May 2014; Revised 26 June 2014; Accepted 16 July 2014; Published 10 August 2014

Academic Editor: Antonio Paz González

Copyright ( 2014 Eiko E. Kuramae et al. This is an open access article distributed under the Creative Commons Attribution License, which permits unrestricted use, distribution, and reproduction in any medium, provided the original work is properly cited.

Land use change alters the structure and composition of microbial communities. However, the links between environmental factors and microbial functions are not well understood. Here we interrogated the functional structure of soil microbial communities across different land uses. In a multivariate regression tree analysis of soil physicochemical properties and genes detected by functional microarrays, the main factor that explained the different microbial community functional structures was $\mathrm{C}: \mathrm{N}$ ratio. $\mathrm{C}: \mathrm{N}$ ratio showed a significant positive correlation with clay and soil $\mathrm{pH}$. Fields with low $\mathrm{C}: \mathrm{N}$ ratio had an overrepresentation of genes for carbon degradation, carbon fixation, metal reductase, and organic remediation categories, while fields with high $\mathrm{C}: \mathrm{N}$ ratio had an overrepresentation of genes encoding dissimilatory sulfate reductase, methane oxidation, nitrification, and nitrogen fixation. The most abundant genes related to carbon degradation comprised bacterial and fungal cellulases; bacterial and fungal chitinases; fungal laccases; and bacterial, fungal, and oomycete polygalacturonases. The high number of genes related to organic remediation was probably driven by high phosphate content, while the high number of genes for nitrification was probably explained by high total nitrogen content. The functional gene diversity found in different soils did not group the sites accordingly to land management. Rather, the soil factors, $\mathrm{C}: \mathrm{N}$ ratio, phosphate, and total $\mathrm{N}$, were the main factors driving the differences in functional genes across the fields examined.

\section{Introduction}

Nutrient cycling within terrestrial ecosystems is mostly performed via the activities of soil-borne microorganisms [1]. With the advent of molecular biological methods, considerable amount of knowledge has been accumulated, concerning the diversity and distribution of microorganisms in soil environments [2-4]. Most of the studies related to the impact of land use change on microbes have focused on the phylogenetic composition of the soil microbial community. With respect to microbial functions in soils, most studies have traditionally been based on enzyme activity screening, with relatively little attention paid to functional marker gene screening [5]. The use of functional gene markers to monitor the presence and activity of genes responsible for key steps in terrestrial nutrient cycles may provide a much more directed approach to the analysis of the nutrient cycling properties of terrestrial ecosystems.

A large amount of knowledge is becoming available concerning the microbial enzymes responsible for the key steps of the major nutrient cycles in soil (i.e., carbon, nitrogen, sulphur, etc.). Recent studies have revealed a great diversity within the genes encoding these key enzymatic processes [610], providing an expanding database representing the known diversity of genes encoding key enzymatic steps involved in nutrient cycling. Microarray technologies have made it possible to represent the diversity of key enzyme functions as an array of probes, which can be interrogated with DNA or RNA extracted from the environment [11-13]. In this way, the total metagenome of an environmental sample can be examined for the presence, diversity, and activity of genes critical to the major nutrient cycles. Coupling such data with 
nutrient flux measurements, enzyme activities, and other measures of soil quality (including phylogenetic microarray data) could potentially provide a quantum advance in our understanding of nutrient cycling in soil systems [14]. Although sequence databases are becoming rather extensive, we clearly have yet to detect the full expanse of the diversity of key enzyme functions, and such microarray-based analyses still necessarily fail to cover all gene families that may be critical to nutrient cycling. Thus, as our knowledge of gene diversity increases, so too will our ability to design probes to monitor a broader range of genes and activities, and such functional microarrays will continue to improve and become more complete as research progresses.

Anthropogenic perturbations (e.g., pollution, fertilizer deposition, and habitat destruction) are known to influence soil nutrient cycles, but little is known about the mechanistic aspects of such disturbances. This lack of knowledge inhibits our ability to assess the extent to which human activities disturb terrestrial nutrient cycling potential and thwarts efforts to predict future anthropogenic impacts. Before the influence of such perturbations can be established or predicted, one must characterize the natural variation and normal operating range with respect to the diversity and expression of key genes related to nutrient cycle functions. To establish such normal operating boundaries, the dynamics of the gene diversity and expression must be monitored across relevant spatial and temporal scales and in response to natural and imposed variability. Although this still remains technically challenging, with hurdles related to limits of signal detection and reproducibility $[15,16]$, functional microarray platforms provide a powerful, high throughput, tool for the detailed assessment of microbial nutrient cycling activities.

In the current study, we exploited the functional structure of microbial communities in soils under different land uses. First, we determined the soil parameters of each field. Next, we tracked the microbial functional communities across land uses. Lastly, we identified links between soil parameters and microbial functions. The main questions addressed in this study were how does the microbial community functional structure vary with different soil managements and what are the main drivers that are related to this variation. In order to answer these questions, we used functional gene arrays (FGA), focussing on crucial steps of key nutrient cycles (C, $\mathrm{N}, \mathrm{P}$, and S) across eight fields representing five generally representative forms of land use (conventional arable field, organic arable field, pasture, natural grassland, and pine forest) in The Netherlands. To our knowledge, this is one of few studies to apply functional microarray technique across a range of different land managements. In addition, this study is one of the first to include a suite of soil measurements to explore the environmental factors driving soil microbial functions under different land uses.

\section{Material and Methods}

2.1. Experimental Design, Sampling, and Soil Analyses. Eight fields subjected to five generally representative forms of land management in The Netherlands (pine forest, natural grasslands, pasture, conventional arable field, and organic arable field) were sampled (Figure S1, Supplementary Material available online at http://dx.doi.org/10.1155/2014/216071) in May 2007; see Table 1. The eight fields were selected from a previous study [17] on soil factors driving microbial community composition in 26 fields across The Netherlands under different land management. In each field, a central point was selected, and subsequently four sampling points at $20 \mathrm{~m}$ of the central point were chosen so as to obtain five samples per field (A, B, C, D, and E). Each sample (A, B, C, $\mathrm{D}$, and $\mathrm{E}$ ) was comprised of five subsamples (A1, A2, A3, A4, A5; B1, B2, B3, B4, B5, etc) from soil cores $(8 \mathrm{~cm}$ diameter $\times 20 \mathrm{~cm}$ deep) taken randomly within a two-meter radius of each of the five sample points A, B, C, D, and E. Soil samples were sieved through a $4 \mathrm{~mm}$ mesh to remove stones, roots, and plant materials. Equal amounts of each of the five subsamples of a given sampling point were pooled, thereby yielding a replication of five composite samples per field. Each composite sample was divided into two parts. One part was stored at $-80^{\circ} \mathrm{C}$ for DNA extraction and the other part kept at $4^{\circ} \mathrm{C}$ for physical and chemical analysis. For physical and chemical analysis, equal amounts of each of the five replicates per field were pooled.

Physicochemical characterization was performed by BLGG (Bedrijfslaboratorium voor Grond en Gewasonderzoek, Wageningen, The Netherlands, http://blgg.agroxpertus $. \mathrm{nl} /$ ). Soil $\mathrm{pH}$ was measured in a $1: 2.5$ soil/water suspension, and soil moisture was determined gravimetrically (g/100 g). Soil organic matter content (\% OM) was determined by loss on ignition (LOI) analysis. Soil texture was determined using a Bouyoucos densimeter after shaking the soil vigorously with $\mathrm{NaOH} 1 \mathrm{M}$ as dispersant. Soil $\mathrm{CaCO}_{3}$ was determined a by Scheibler's method. Phosphate $(\mathrm{P})$ was determined as the amount extracted from a soil after addition of water at a shaking ratio of $1: 60$, a procedure typically used to determine the soil fertility status of arable fields in The Netherlands. Cr, $\mathrm{Cu}, \mathrm{Hg}, \mathrm{As}, \mathrm{Ni}, \mathrm{Cd}, \mathrm{Pb}$, and $\mathrm{Zn}$ were extracted by Mehlich 1 and determined by atomic absorption spectrometry.

2.2. DNA Extraction, Amplification, Labelling, and Hybridization. DNA extractions were performed separately on each of the five replicates per field using the MoBio Power Soil Extraction kit (MoBio, Carlsbad, CA, USA) with bead-beating (Restch MM301, Retsch GmbH, Germany) at $5.5 \mathrm{~m} \mathrm{~s}^{-1}$ for $10 \mathrm{~min}$. Total DNA concentration was quantified on a ND1000 spectrophotometer (Nanodrop Technology, Wilmington, DE, USA).

The DNAs from replicates of each sample were pooled. Because the amount of DNA extracted was in most cases insufficient for direct labeling and hybridization, $30 \mathrm{ng}$ of DNA per sample was amplified by whole community rolling cycle amplification (WCRCA) using a TempliPhi kit (GE Healthcare, Piscataway, NJ). We used the GeoChip functional microarray platform, which contains more than 24,000 oligonucleotide (50-mer) probes targeting targeted approximately 10,000 genes involved in nitrogen, carbon, sulfur and phosphorus transformations and cycling, metal reduction 


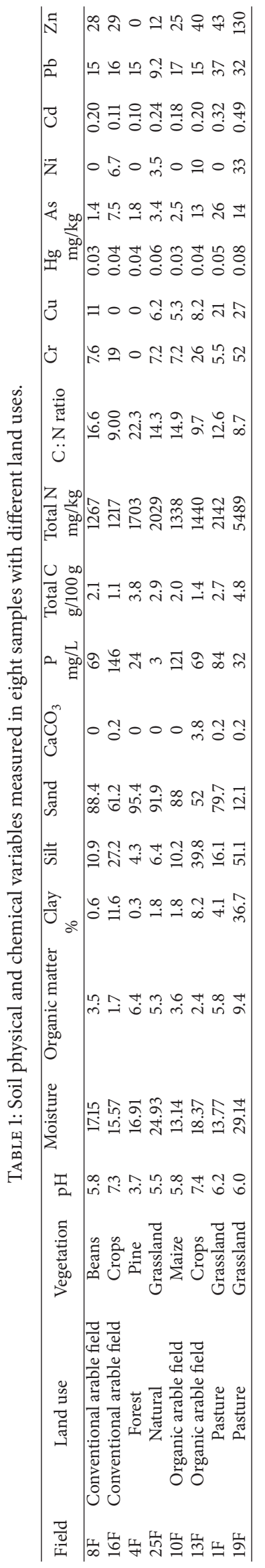


TABLE 2: Total number and percentage of functional genes unique and overlapping in samples of different land uses.

\begin{tabular}{|c|c|c|c|c|c|c|c|c|}
\hline$\%$ of genes & $25 \mathrm{~F}$ & $19 \mathrm{~F}$ & $16 \mathrm{~F}$ & $13 \mathrm{~F}$ & $10 \mathrm{~F}$ & $8 \mathrm{~F}$ & $4 \mathrm{~F}$ & $1 \mathrm{~F}$ \\
\hline $25 \mathrm{~F}$ & $13(6.9)$ & $132(19.7)$ & $136(23.8)$ & $145(14.5)$ & $119(31.4)$ & $61(20.4)$ & $123(22.1)$ & $72(27.6)$ \\
\hline $19 \mathrm{~F}$ & & $113(18.4)$ & $300(36.0)$ & $429(37.6)$ & $214(30.1)$ & $107(15.7)$ & $264(31.3)$ & $109(16.7)$ \\
\hline $16 \mathrm{~F}$ & & & $72(13.8)$ & $381(34.8)$ & $206(33.0)$ & $110(18.9)$ & $251(33.0)$ & $116(21.1)$ \\
\hline $13 \mathrm{~F}$ & & & & $319(33.4)$ & $254(25.1)$ & $133(13.3)$ & $328(29.3)$ & $120(12.2)$ \\
\hline $10 \mathrm{~F}$ & & & & & $16(5.1)$ & $100(26.0)$ & $186(30.1)$ & $94(25.9)$ \\
\hline $8 \mathrm{~F}$ & & & & & & $16(9.2)$ & $96(16.8)$ & $59(22.7)$ \\
\hline $4 \mathrm{~F}$ & & & & & & & $97(19.7)$ & $120(23.1)$ \\
\hline $1 \mathrm{~F}$ & & & & & & & & $4(2.7)$ \\
\hline Total number of genes & 187 & 614 & 520 & 956 & 311 & 173 & 493 & 146 \\
\hline
\end{tabular}

Italic numbers represent unique genes in each soil sample.

The remaining numbers represent the numbers of genes and their percentage (in parenthesis) overlapping between two samples.

and resistance and organic xenobiotic degradation [18]. The number of technical replicates for microarray hybridization was four for samples of fields $1 \mathrm{~F}, 4 \mathrm{~F}, 10 \mathrm{~F}, 13 \mathrm{~F}, 16 \mathrm{~F}$, $19 \mathrm{~F}$, and $25 \mathrm{~F}$ and three for field $8 \mathrm{~F}$. The amplified DNAs were labelled with a Cy5 fluorescent dye, purified, and then hybridized to the GeoChip functional array (FGA II) [18] in a Tecan hybridization station (Durham, NC) at $42^{\circ} \mathrm{C}$ for 10 hours. Arrays were washed, dried, and scanned using a ScanArray 5000. The signal intensity for each probe was determined digitally by Imagene software (Biodiscovery Inc., Los Angeles, CA).

2.3. Microarray Data Processing and Analysis. The data processing was according to $\mathrm{He}$ et al. [18]. Each array was cleaned by deleting flag 1.3 and SNR $<2$ and normalized by mean of all spots in the same slide. The final table of all intensities of all samples were obtained by removing the outline spots more than 2 sigma, the maximal ratio between spots was 3 if certain genes had only 2 spots in the array, the spots with final spot numbers was 0.51 times less than the original number and the minimal spots number for a gene was 2 .

2.4. Statistical Analysis. Pearson correlations were calculated between soil factors (total $\mathrm{C}$, total $\mathrm{N}, \mathrm{C}: \mathrm{N}$ ratio, organic matter, soil $\mathrm{pH}, \mathrm{CaCO}_{3}, \mathrm{Cr}, \mathrm{Cu}, \mathrm{P}, \mathrm{Zn}$, soil texture, and soil moisture) using the "multtest" package in $\mathrm{R}$ (version 2.6.0, The R Foundation for Statistical Computing). $P$ values were corrected for multiple testing, using the false discovery rate controlling procedure [19]. The probe intensities and soil physicochemical factors were used for multivariate regression tree (MRT) analysis by using the "mvpart" package in $\mathrm{R}$, and the distance matrix was based on Bray-Curtis built by the function "gdist."

Microbial community functional structure was related to soil factors using canonical correspondence analyses (CCA) in Canoco 4.5 for Windows [20]. Probe intensities were used as "species" data, while soil data was included in the analysis as "environmental" variables. Variables having the most significant influence on the microbial community structure were chosen by forward selection with a $P<0.01$ baseline. The variables selected this way were then included in a model whose significance was tested with 999 permutations.
Gene functional category and land fields were added as extra variables but not involved in the calculations.

\section{Results and Discussion}

3.1. Soil Properties. In general, the pasture field 19F was very different from the other fields with highest cadmium, clay, chromium, copper, mercury, nickel, organic matter, silt, total carbon, total nitrogen, and zinc contents (Table 1). The pine forest $4 \mathrm{~F}$ had higher $\mathrm{C}: \mathrm{N}$ ratio, sand, and total $\mathrm{C}$ contents and lower cadmium, clay, chromium, $\mathrm{pH}$, phosphate, and zinc contents than the other sites (Table 1). The highest percentage of $\mathrm{CaCO}_{3}$ was found in organic arable field 13F. The soil moisture at the time of sampling varied among fields. The moisture contents of $19 \mathrm{~F}$ and $25 \mathrm{~F}$ fields were the highest, while moisture contents of $10 \mathrm{~F}$ and $1 \mathrm{~F}$ fields were the lowest (Table 1).

The correlation analyses showed significant correlation between several soil factors. Soil $\mathrm{pH}$ was negatively correlated with $\mathrm{C}: \mathrm{N}$ ratio. $\mathrm{C}: \mathrm{N}$ ratio was negatively correlated with silt and chromium and positively correlated with sand. Total $\mathrm{N}$ was positively correlated with total C, organic matter, clay, chromium, and zinc and negatively correlated with sand. Chromium and zinc were positively correlated (Table S1).

3.2. Microarray Analyses. A total of 1405 genes across all samples were detected. The pasture field $1 \mathrm{~F}$ had the lowest numbers of genes (146) detected by the GeoChip followed by conventional arable field $8 \mathrm{~F}$ (173 genes) and natural grassland field $25 \mathrm{~F}$ (Table 2). The organic arable field $13 \mathrm{~F}$ had the highest number of genes detected (956). The pasture field $1 \mathrm{~F}$ with lower functional gene number had high overlap with communities of natural grassland 25F (27.6\%) and organic arable field 10F (25.9\%) (Table 2). The shared genes between two or more field-soils varied from 12.2 to $37.6 \%$, and the numbers of unique genes identified in only one soil were relative very small, varying from 2.7 to $19.7 \%$, except for organic arable field $13 \mathrm{~F}$ (33.4\%) (Table 2). Although there were large differences in the number of genes detected in each field, fields with similar soil characteristics, such as high total nitrogen in $1 \mathrm{~F}, 25 \mathrm{~F}$, and $10 \mathrm{~F}$ and low phosphate content 


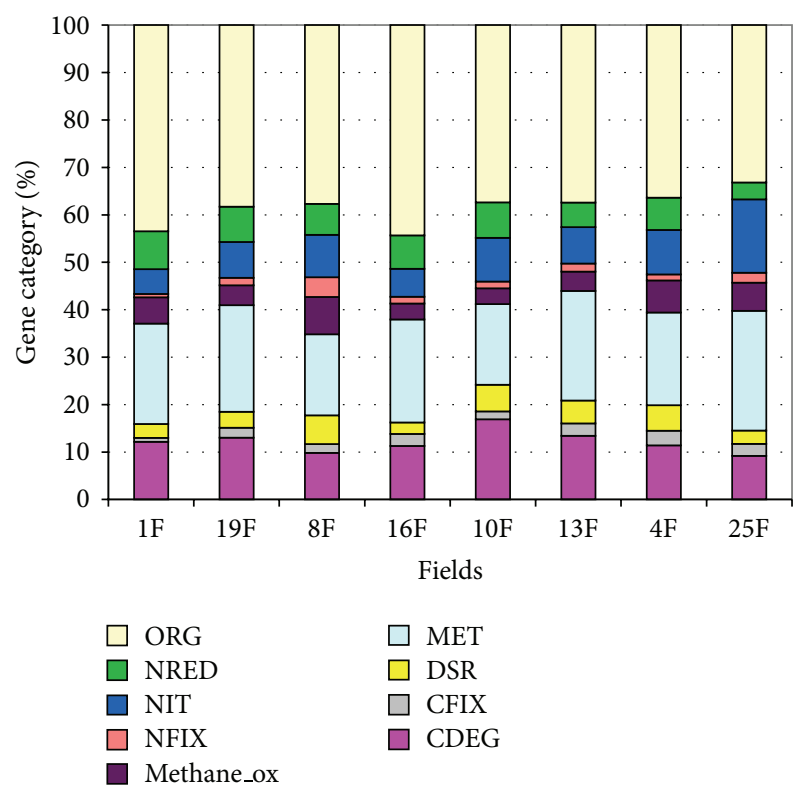

Figure 1: Percentage of gene categories given in the GeoChip present in soils from different land uses: pasture $(1 \mathrm{~F}, 19 \mathrm{~F})$, conventional arable field $(8 \mathrm{~F}, 16 \mathrm{~F})$, organic arable field (10F, $13 \mathrm{~F})$, forest $(4 \mathrm{~F})$, and natural grassland (25F). CDEG: carbon degradation; CFIX: carbon fixation; DSR: dissimilatory sulfate reductase; MET: metal reductase; Methane_ox: methane oxidation NFIX: nitrogen fixation; NIT: nitrification; NRED: nitrogen reductase; ORG: organic remediation.

(Figure 2) in 13F and 19F showed the most overlap in detected genes.

In general, there were differences in microbial community functional structure among the study sites (Figure 1). The percentage of genes related to carbon degradation (17\%) was highest in organic arable fields $(10 \mathrm{~F})$ and lowest in natural grassland $25 \mathrm{~F}$. This low representation of carbon degradation genes in field $25 \mathrm{~F}$ is somewhat expected, as this particular field represents a typical Dutch "Blauwgrasland" soil type, which is often inundated and therefore exposed to anaerobic conditions. Indeed, soil water content impacts oxygen diffusion what higher moisture content leads to decrease in organic matter decomposition due to low oxygen supply [21]. Genes detected for carbon fixation were generally similar across the soils examined, except for $10 \mathrm{~F}$ and $1 \mathrm{~F}$ fields, which both had a lower percentage of genes from this category. Interestingly, these two fields had the lowest soil moisture contents. Dissimilatory sulfate reductase genes were highest (5-6\%) in soils from filed 4F, 8F, and 10F. Pine forest field $4 \mathrm{~F}$ and conventional arable field $8 \mathrm{~F}$ had higher percentages (6$7 \%$ ) of genes of methane oxidation. The conventional arable field $8 \mathrm{~F}$ had highest number of genes of nitrogen fixation (4\%), while fields $16 \mathrm{~F}$ and $1 \mathrm{~F}$ had highest gene numbers for organic remediation (44\%) (Figure 1).

In a multivariate regression tree (MRT) analysis, combining the measured soil factors $(\mathrm{pH}$, total $\mathrm{N}$, total $\mathrm{C}, \mathrm{C}: \mathrm{N}$ ratio, organic matter, phosphate, clay, silt, sand, $\mathrm{CaCO}_{3}, \mathrm{Cd}, \mathrm{Cr}, \mathrm{Cu}$, $\mathrm{Ni}, \mathrm{Pb}, \mathrm{Zn}, \mathrm{As}$, and $\mathrm{Hg}$ ) and the intensities of the 1405 genes detected by the GeoChip, the main factor that explained the microbial community functional structure differences in the eight fields was $\mathrm{C}: \mathrm{N}$ ratio (Figure 2). $\mathrm{C}: \mathrm{N}$ ratio differentiated the fields into two main groups: (a) fields $16 \mathrm{~F}$ (conventional arable field), 19F (pasture), and 13F (organic arable field) with $\mathrm{C}: \mathrm{N}$ ratio lower than 11.15 and (b) fields $10 \mathrm{~F}$ (organic arable field), 4F (pine forest), 25F (natural grassland), 1F (pasture), and $8 \mathrm{~F}$ (conventional arable field) with $\mathrm{C}: \mathrm{N}$ ratio higher than 11.15. The clustering of the three fields $13 \mathrm{~F}, 16 \mathrm{~F}$, and $19 \mathrm{~F}$ with $\mathrm{C}: \mathrm{N}$ ratio lower than 11.16 also corresponds to less sand in the soil texture and higher soil $\mathrm{pH}$ as compared to the other fields, as $\mathrm{C}: \mathrm{N}$ was significantly positively correlated with sand and soil $\mathrm{pH}$.

The main differences between the two clusters A/B (fields $16 \mathrm{~F}, 13 \mathrm{~F}$, and 19F) and C/D (fields 1F, 4F, 10F, 25F, and 8F) were that fields with $\mathrm{C}: \mathrm{N}$ ratios lower than 11 had more genes for carbon degradation (CDEG), carbon fixation (CFIX), metal reductase (MET), and organic remediation (ORG) categories than the fields with $\mathrm{C}: \mathrm{N}$ ratio higher than $11 . \mathrm{C}: \mathrm{N}$ ratio is known to have a large influence on decomposition rates [22]. Fields $16 \mathrm{~F}, 13 \mathrm{~F}$, and $19 \mathrm{~F}$ had the lowest $\mathrm{C}: \mathrm{N}$ ratios. It is expected that soils with lower $\mathrm{C}: \mathrm{N}$ ratios will contain more easily decomposable organic matters as compared to soils with high $\mathrm{C}: \mathrm{N}$ ratios [23]. Our results are consistent with this expectation, with higher numbers of carbon degradation genes in those sites with lowest $\mathrm{C}: \mathrm{N}$ ratios. In addition, $\mathrm{CO}_{2}$ is released into the environment during the organic material decomposition, and this may explain the high numbers of microbial carbon fixation genes [24] in fields 16F, 13F, and $19 \mathrm{~F}$. On the other hand, fields with a $\mathrm{C}: \mathrm{N}$ ratio higher than 11 showed more genes from categories dissimilatory sulfate reductase (DSR), methane oxidation, nitrification (NIT), and nitrogen fixation (NFIX) than fields with $\mathrm{C}: \mathrm{N}$ lower than 11 (Figure 2).

Among fields with $\mathrm{C}: \mathrm{N}$ ratio lower than 11, field $16 \mathrm{~F}$ had the highest number of genes of the organic remediation (ORG) category. This may be related to the high amount of phosphate in this soil-that is, greater than $107 \mathrm{mg} / \mathrm{kg}$ soil as calculated in MRT analysis and illustrated in the CCA plot (Figure 3). On the other hand, the high percentage of genes for CDEG and MET in fields $13 \mathrm{~F}$ and $19 \mathrm{~F}$ appeared to be explained by lower phosphate concentrations (less than $107 \mathrm{mg} / \mathrm{kg}$; Figure 2). The higher phosphate contents in fields $13 \mathrm{~F}, 16 \mathrm{~F}, 19 \mathrm{~F}$ and $16 \mathrm{~F}$ may be related to the high clay content of these soils, as it is well known that phosphate availability strongly depends on clay quantity and quality [25].

The genes detected within the ORG category in $16 \mathrm{~F}$ are related to a range of degradation activities (Table S2). In fact, phosphate has been shown to be an important nutrient factor required by bacterial biofilter for maximum methane elimination [26]. The field $16 \mathrm{~F}$ is a conventional arable field that has been intensively cultivated with different crops. It has therefore been subjected to high inputs of inorganic fertilizers such as nitrogen, phosphate, and potassium. Phosphate was negatively correlated with total $\mathrm{C}$ and total $\mathrm{C}$ was positively correlated with organic matter content. In other words, the fields $13 \mathrm{~F}$ and $19 \mathrm{~F}$ had higher total carbon, higher organic matter and lower phosphate than field 16F, and these properties seem to be favourable for genes involved in carbon 


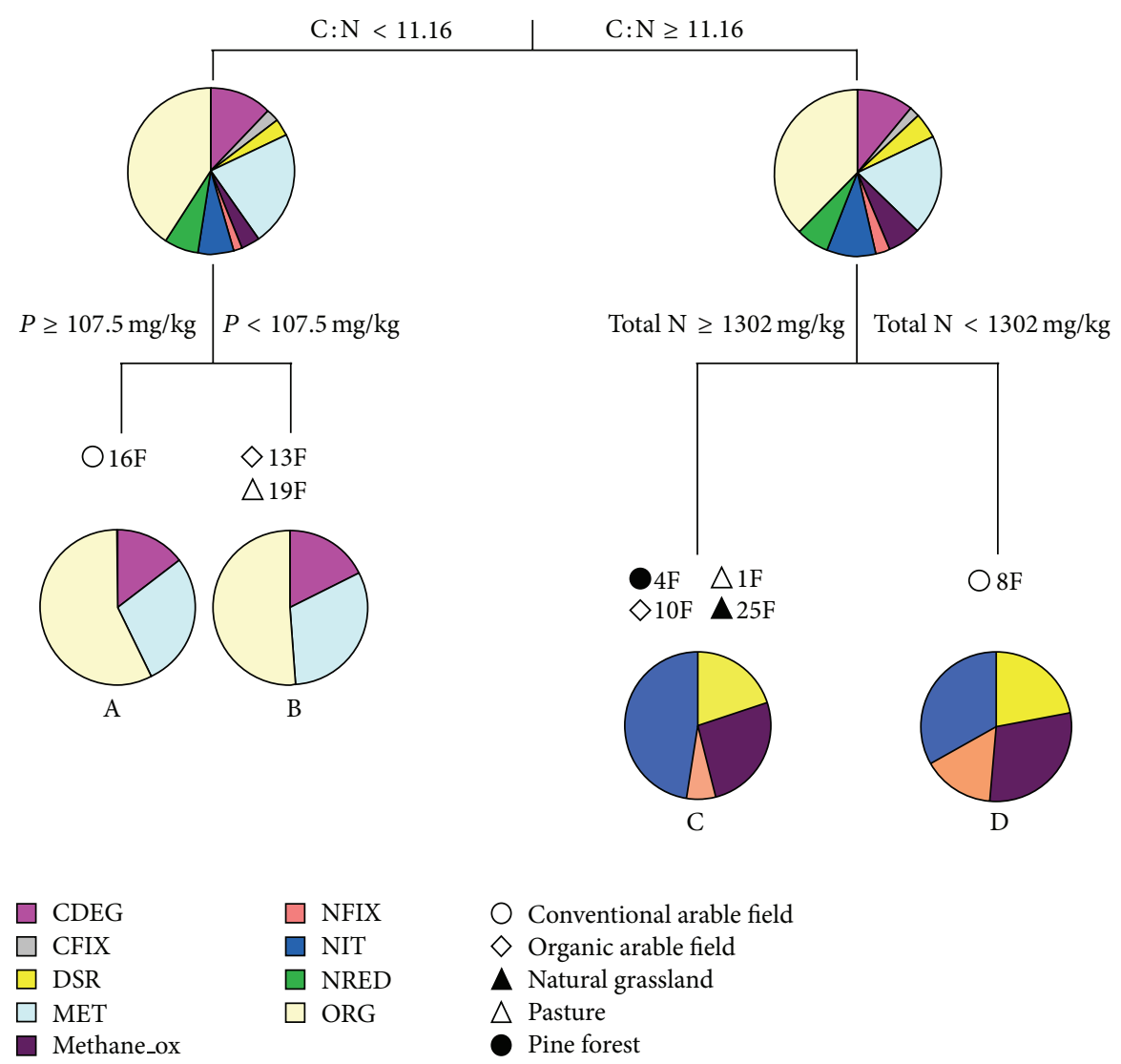

FIGURE 2: Multivariate regression tree (MRT) analysis of soil physicochemical properties and GeoChips intensities given by samples of fields 1F, 4F, 8F, 10F, 13F, 16F, 19F, and 25F. A, B, C, and D are clusters.

degradation (CDEG) and metal reductase (MET) activities (Figures 2 and 3). The CDEG genes overrepresented in samples $13 \mathrm{~F}$ and $16 \mathrm{~F}$ were related to bacterial and fungal cellulases; bacterial and fungal chitinases; fungal laccases; and bacterial, fungal, and oomycete polygalacturonases (Table S3). The MET genes overrepresented in these same fields $13 \mathrm{~F}$ and $19 \mathrm{~F}$ were genes encoding reductases of aluminium, arsenic, cadmium, chromium, cobalt, copper, cytochrome, lead, mercury, nickel, tellurium, and vanadium (Table S3), and some soil chemicals, that is, cadmium, chromium, copper, mercury, and nickel, were indeed highest in the pasture field 19F (Table 1).

Fields with a $\mathrm{C}: \mathrm{N}$ ratio higher than $11(1 \mathrm{~F}, 4 \mathrm{~F}, 10 \mathrm{~F}$, and $25 \mathrm{~F}$ ) had relatively high percentages of genes of nitrification (NIT), and high levels of total nitrogen (i.e., $>1302 \mathrm{mg} / \mathrm{kg}$ ) appeared to explain this result. The field $8 \mathrm{~F}$ had the highest numbers of genes from categories for dissimilatory sulfate reductase, methane oxidation, and nitrogen fixation, and this pattern was explained by total $\mathrm{N}$ levels lower than $1302 \mathrm{mg} / \mathrm{kg}$ soil (Figure 2). The higher percentage of nitrogen fixation genes in field $8 \mathrm{~F}$ than fields $1 \mathrm{~F}, 4 \mathrm{~F}, 10 \mathrm{~F}$, and $25 \mathrm{~F}$ can be explained by the presence of nitrogen-fixing bacteria in this particular soil, probably related to the growth of legumes (beans) at this site. The nitrification-related genes abundant in fields $1 \mathrm{~F}, 4 \mathrm{~F}, 10 \mathrm{~F}$, and $25 \mathrm{~F}$ were ureases, amoA, pmoA, and ghd. The DSR genes abundant in $8 \mathrm{~F}$ were $d s r \mathrm{~A}$ and $d s r \mathrm{~B}$; the methanol-oxidation category was dominated by $p m o \mathrm{~A}$ and $m m o \mathrm{~A}$ from methanotrophs and nitrogen fixation genes categorized as nif $\mathrm{H}$ from nitrogen-fixing bacteria (Table S4).

The nitrification genes found in fields $1 \mathrm{~F}, 4 \mathrm{~F}, 10 \mathrm{~F}$, and $25 \mathrm{~F}$ were similar to uncultured ammonia-oxidizing $\beta$-Proteobacteria amoA genes. Ureases (E.C. 3.5.1.5) are complex metalloenzymes that catalyze the hydrolysis of urea to ammonia and carbon dioxide. This enzyme allows many soil bacteria to use urea as nitrogen source, and we detected several ureases in nitrogen-fixing bacteria such as Mesorhizobium loti, Bradyrhizobium japonicus, Rhodopseudomonas palustris, Rhodobacter sphaeroides, Rhodobacter ( $\alpha$-Proteobacteria), Chromobacterium violaceum ( $\beta$-Proteobacteria), and Nostoc (Cyanobacteria) (Table S4). Urease is also an important virulence factor that improves survival of pathogenic bacteria in harsh conditions within the host and causes direct damage to the host due to ammonium, $\mathrm{CO}_{2}$, or alkali production (for reviews see $[27,28]$ ), and in our study we found ureases similar to those of plant pathogens such Pseudomonas syringae, Klebsiella aerogenes, ( $\gamma$-Proteobacteria), Mycobacterium (Actinobacteria), and Brucella melitensis ( $\alpha$ Proteobacteria) (Table S4).

Fields $4 \mathrm{~F}$ and $25 \mathrm{~F}$ had distinct soil properties or conditions that would be expected to impact numerous microbial processes. However, we found no evidence for a sharp distinction in the functional gene repertoires of these communities. 


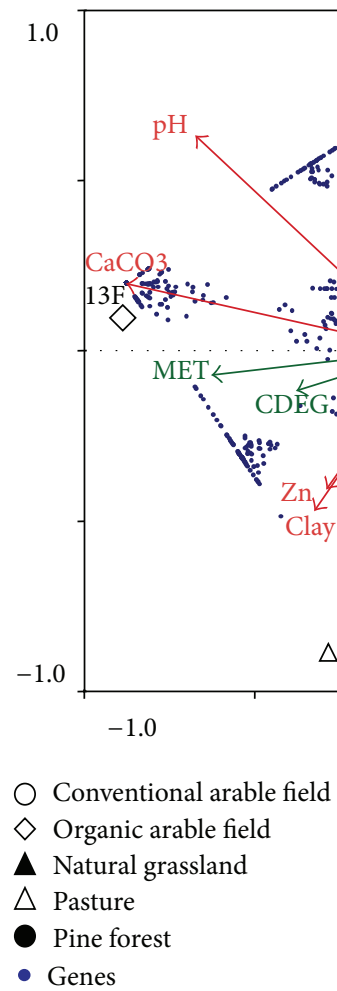

ORG: organic remediation

Figure 3: Canonical correspondence analysis (CCA) triplot of soil physicochemical properties (red arrows), GeoChips intensities (dots) with functional categories (green arrows), and eight fields with different land uses.

Field $4 \mathrm{~F}$ was extremely acidic which distinguishes it from other natural and cultivated soils. In fact, in a previous study on microbial community composition across 26 fields under different land uses including the eight fields here studied, Kuramae et al. [17] found that field $4 \mathrm{~F}$ had the most distinct microbial community composition. This difference was linked to low $\mathrm{pH}$ and high $\mathrm{C}: \mathrm{N}$ ratio. However, in the present study, $4 \mathrm{~F}$ and $25 \mathrm{~F}$ have similar microbial function profiles, despite the differences in soil $\mathrm{pH}, \mathrm{C}: \mathrm{N}$ ratio, and moisture. Thus, it appears to be that soil microbial composition is more sensitive to changes in soil $\mathrm{pH}$ than the functional capability of the community. This may be due to the function redundancy present in soil communities. In addition, the soil factors that drive microbial composition are not the same as those driving microbial potential function structures.

\section{Conclusion}

The soil-borne microbial functional structure in the different fields in The Netherlands did not group the sites accordingly to land management. Although the number of fields examined here was limited to eight, the breadth of our study was sufficient to assess the differences in microbial functional genes in different systems of soil management, and specific soil factors could be identified that explained the differences observed in functional gene composition of the different soils examined.

\section{Conflict of Interests}

The authors declare that there is no conflict of interests regarding the publication of this paper.

\section{Acknowledgments}

The authors thank Dr. Z. He and Dr. Y. Deng (Institute of Environmental Genomics, The University of Oklahoma) for laboratory and bioinformatics assistance and thank Dr. Bart Pietersen (BDS-BioDetection System), Remy Hillekens (NIOO-KNAW), and Dr. Tjalf de Boer (Vrij University of Amsterdam) for assistance in soil sampling. Publication number 5639 of the Netherlands Institute of Ecology (NIOOKNAW).

\section{References}

[1] J. I. Prosser, "Ecosystem processes and interactions in a morass of diversity," FEMS Microbiology Ecology, vol. 81, no. 3, pp. 507519, 2012.

[2] V. Torsvik and L. Øvreås, "Microbial diversity and function in soil: from genes to ecosystems," Current Opinion in Microbiology, vol. 5, no. 3, pp. 240-245, 2002.

[3] E. A. Dinsdale, R. A. Edwards, D. Hall et al., "Functional metagenomic profiling of nine biomes," Nature, vol. 452, no. 7214, pp. 629-632, 2008.

[4] A. A. Navarrete, E. E. Kuramae, M. de Hollander, A. S. Pijl, J. A. van Veen, and S. M. Tsai, "Acidobacterial community responses to agricultural management of soybean in Amazon forest soils," FEMS Microbiology Ecology, vol. 83, no. 3, pp. 607-621, 2013.

[5] G. A. Kowalchuk, B. Drigo, E. Yergeau, and J. A. van Veen, "Molecular approaches to assess the structure of bacterial and fungal communities in soil-the use of rRNA and other gene markers," in Nucleic Acids and Proteins in Soil, P. Nannipieri and K. Smalla, Eds., pp. 159-188, Springer, Heidelberg, Germany, 2006.

[6] A. Priemé, G. Braker, and J. M. Tiedje, "Diversity of nitrite reductase (nirK and nirS) gene fragments in forested upland and wetland soils," Applied and Environmental Microbiology, vol. 68, no. 4, pp. 1893-1900, 2002.

[7] G. Braker and J. M. Tiedje, "Nitric oxide reductase (norB) genes from pure cultures and environmental samples," Applied and Environmental Microbiology, vol. 69, no. 6, pp. 3476-3483, 2003.

[8] T. Yan, M. W. Fields, L. Wu, Y. Zu, J. M. Tiedje, and J. Zhou, "Molecular diversity and characterization of nitrite reductase gene fragments (nirK and nirS) from nitrate- and uraniumcontaminated groundwater," Environmental Microbiology, vol. 5, no. 1, pp. 13-24, 2003.

[9] X. D. Liu, S. M. Tiquia, G. Holguin et al., "Molecular diversity of denitrifying genes in continental margin sediments within the oxygen-deficient zone off the Pacific coast of Mexico," Applied and Environmental Microbiology, vol. 69, no. 6, pp. 3549-3560, 2003.

[10] S. W. Lee, J. Im, A. A. Dispirito, L. Bodrossy, M. J. Barcelona, and J. D. Semrau, "Effect of nutrient and selective inhibitor amendments on methane oxidation, nitrous oxide production, and key gene presence and expression in landfill cover soils: characterization of the role of methanotrophs, nitrifiers, and denitrifiers," Applied Microbiology and Biotechnology, vol. 85, no. 2, pp. 389-403, 2009. 
[11] L. Wu, L. Kellogg, A. H. Devol, J. M. Tiedje, and J. Zhou, "Microarray-based characterization of microbial community functional structure and heterogeneity in marine sediments from the Gulf of Mexico," Applied and Environmental Microbiology, vol. 74, no. 14, pp. 4516-4529, 2008.

[12] Z. He, Y. Deng, J. D. van Nostrand et al., "GeoChip 3.0 as a high-throughput tool for analyzing microbial community composition, structure and functional activity," ISME Journal, vol. 7, no. 9, pp. 1167-1179, 2010.

[13] J. R. Reeve, C. W. Schadt, L. Carpenter-Boggs, S. Kang, J. Zhou, and J. P. Reganold, "Effects of soil type and farm management on soil ecological functional genes and microbial activities," ISME Journal, vol. 4, no. 9, pp. 1099-1107, 2010.

[14] E. M. H. Wellington, A. Berry, and M. Krsek, "Resolving functional diversity in relation to microbial community structure in soil: exploiting genomics and stable isotope probing," Current Opinion in Microbiology, vol. 6, no. 3, pp. 295-301, 2003.

[15] J. Zhou and D. K. Thompson, "Challenges in applying microarrays to environmental studies," Current Opinion in Biotechnology, vol. 13, no. 3, pp. 204-207, 2002.

[16] V. J. Denef, J. Park, J. L. M. Rodrigues, T. V. Tsoi, S. A. Hashsham, and J. M. Tiedje, "Validation of a more sensitive method for using spotted oligonucleotide DNA microarrays for functional genomics studies on bacterial communities," Environmental Microbiology, vol. 5, no. 10, pp. 933-943, 2003.

[17] E. E. Kuramae, E. Yergeau, L. C. Wong, A. S. Pijl, J. A. Van Veen, and G. A. Kowalchuk, "Soil characteristics more strongly influence soil bacterial communities than land-use type," FEMS Microbiology Ecology, vol. 79, no. 1, pp. 12-24, 2012.

[18] Z. He, T. J. Gentry, C. W. Schadt et al., "GeoChip: a comprehensive microarray for investigating biogeochemical, ecological and environmental processes," ISME Journal, vol. 1, no. 1, pp. 6777, 2007.

[19] Y. Benjamini and Y. Hochberg, "Controlling the false discovery rate: a practical and powerful approach to multiple testing," Journal of the Royal Statistical Society B: Methodological, vol. 57, no. 1, pp. 289-300, 1995.

[20] C. J. F. ter Braak and P. Šmilauer, CANOCO Reference Manual and CanoDraw for Windows User's Guide: Software for Canonical Community Ordination (Version 4.5), Microcomputer Power, Ithaca, NY, USA, 2002.

[21] K. Killham, M. Amato, and J. N. Ladd, "Effect of substrate location in soil and soil pore-water regime on carbon turnover," Soil Biology and Biochemistry, vol. 25, no. 1, pp. 57-62, 1993.

[22] S. Manzoni, R. B. Jackson, J. A. Trofymow, and A. Porporato, "The global stoichiometry of litter nitrogen mineralization," Science, vol. 321, no. 5889, pp. 684-686, 2008.

[23] M. W. I. Schmidt, M. S. Torn, S. Abiven et al., "Persistence of soil organic matter as an ecosystem property," Nature, vol. 478, no. 7367, pp. 49-56, 2011.

[24] X. H. Wu, T. D. Ge, H. Z. Yuan et al., "Changes in bacterial $\mathrm{CO}_{2}$ fixation with depth in agricultural soils," Appiedl Microbiology Biotechnology, vol. 98, no. 5, pp. 2309-2319, 2014.

[25] J. K. Edzwald, D. C. Toensing, and M. C. Leung, "Phosphate adsorption reactions with clay minerals," Environmental Science and Technology, vol. 10, no. 5, pp. 485-490, 1976.

[26] J. Nikiema, R. Brzezinski, and M. Heitz, "Influence of phosphorus, potassium, and copper on methane biofiltration performance," Canadian Journal of Civil Engineering, vol. 37, no. 2, pp. 335-345, 2010.
[27] H. L. T. Mobley and R. P. Hausinger, "Microbial ureases: significance, regulation, and molecular characterization," Microbiological Reviews, vol. 53, no. 1, pp. 85-108, 1989.

[28] H. L. T. Mobley, M. D. Island, and R. P. Hausinger, "Molecular biology of microbial ureases," Microbiological Reviews, vol. 59, no. 3, pp. 451-480, 1995. 

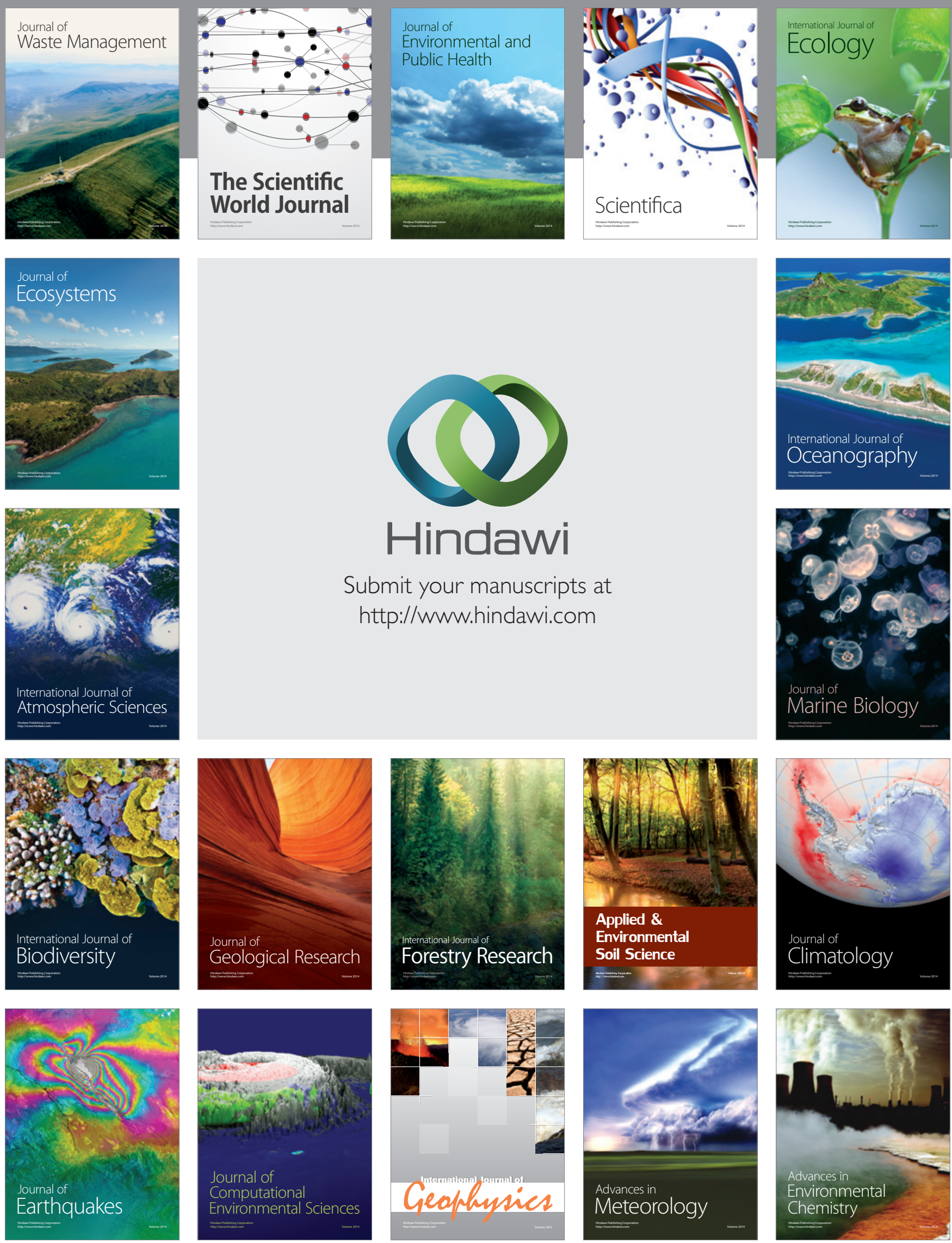